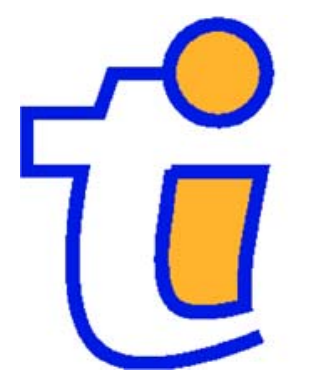

TI 2010-043/3

Tinbergen Institute Discussion Paper

The Impact of Monetary Policy on Economic Activity Evidence from a Meta-Analysis

Version: 21 April 2010

Masagus M. Ridhwana,b,c

Henri L.F. de Groot ${ }^{a, b}$

Peter Nijkampa,b

Piet Rietvelda,b

a VU University Amsterdam, and

b Tinbergen Institute, the Netherlands;

c Bank Indonesia, Jakarta, Indonesia. 


\section{Tinbergen Institute}

The Tinbergen Institute is the institute for economic research of the Erasmus Universiteit Rotterdam, Universiteit van Amsterdam, and Vrije Universiteit Amsterdam.

Tinbergen Institute Amsterdam

Roetersstraat 31

1018 WB Amsterdam

The Netherlands

Tel.: +31(0)205513500

Fax: $+31(0) 205513555$

Tinbergen Institute Rotterdam

Burg. Oudlaan 50

3062 PA Rotterdam

The Netherlands

Tel.: + $31(0) 104088900$

Fax: $+31(0) 104089031$

Most TI discussion papers can be downloaded at http://www.tinbergen.nl. 


\title{
The Impact of Monetary Policy on Economic Activity
}

\section{Evidence from a Meta-Analysis}

Masagus M. Ridhwan ${ }^{\mathrm{a}, \mathrm{b}, \mathrm{c}}$, Henri L.F. de Groot ${ }^{\mathrm{a}, \mathrm{b}}$, Peter Nijkamp ${ }^{\mathrm{a}, \mathrm{b}}$, Piet Rietveld ${ }^{\mathrm{a}, \mathrm{b}, 1}$

${ }^{a}$ VU University Amsterdam, Department of Spatial Economics, The Netherlands

${ }^{\mathrm{b}}$ Tinbergen Institute, Amsterdam-Rotterdam, The Netherlands

${ }^{\mathrm{c}}$ Bank Indonesia, Jakarta, Indonesia

\begin{abstract}
This paper presents the findings a meta-analysis identifying the causes of variation in the impact of monetary policies on economic development. The sample of observations included in our meta-analysis is drawn from primary studies that uniformly employ Vector Autoregressive (VAR) models. Our findings reveal that capital intensity, financial deepening, the inflation rate, and economic size are important in explaining the variation in outcomes across regions and over time. Differences in the type of models used in the primary studies also significantly contribute to the explanation of the variation in study outcomes.
\end{abstract}

Keywords: $\quad$ Monetary policy, Economic development, Meta-analysis

JEL codes: $\quad \mathrm{E} 52, \mathrm{R} 11, \mathrm{C} 83$

\footnotetext{
${ }^{1}$ We are grateful to Patricia Stekelenburg for excellent research assistance. Corresponding author: Henri L.F. de Groot, Department of Spatial Economics, VU University Amsterdam, De Boelelaan 1105, 1081 HV Amsterdam, The Netherlands. Email: hgroot@feweb.vu.nl
} 
" Though many macroeconomists would profess little uncertainty about it, the profession as a whole has no clear answer to the question of the size and nature of the effects of monetary policy on aggregate activity" (Sims, 1992, p. 975)

\section{Introduction}

The impact of monetary policy on the real economy has been a contentious area in macroeconomics (see Bernanke and Gertler, 1995). The quest for 'what is inside the blackbox' conventionally posits whether changing interest rates have an impact on real economic variables, and, if so, how large these effects are. ${ }^{2}$ The debate is even more pronounced when it boils down to the regional level, since monetary policies inherently address national targets, while different regions within a monetary union exhibit different structures and characteristics. Hence, they may respond asymmetrically to the impulses of a uniform monetary policy. As a consequence, it will have distributional implications across regions, as economic activity in a core region may be stimulated by the policy, while the periphery may become more depressed (see, for example, Ridhwan et al., 2008, for a discussion). Such distributional effects are of particular interest in view of the advent of the European Monetary Union (EMU) and currency areas more generally.

In order to unravel such issues, numerous studies have attempted to identify the effects of monetary policies. For instance, Carlino and DeFina (1998, 1999), and Owyang and Wall (2004) have looked at the USA, while Ramaswamy and Sløk (1998) and Clements et al. (2001) have studied European countries. In general, their findings suggest differential output effects in response to a common policy shock. Other studies especially on European countries have concluded that the output effects in the eurozone are very similar (see, for example, Peersman, 2004). Gerlach and Smets (1995) and Kieler and Saarenheimo (1998) conclude that there is little or no variation in the monetary transmission across the countries. These conflicting findings tend to indicate that there are still substantially different views on the actual impact of monetary policy. ${ }^{3}$

\footnotetext{
${ }^{2}$ Other monetary transmission channels that are described in the monetary policy literature are the bank-lending channel, the exchange rate channel, the expectations channel, and the asset-price channel (see, for example, Mishkin, 1995, 1996).

${ }^{3}$ A different but related issue that we do not address here focuses on the asymmetry in impact on output of tight versus easy monetary policies. Cover (1992) presents early evidence that positive money-supply shocks have no effect on output, whereas negative money-supply shocks cause output to decline. Other studies by De Long and Summers (1988) and Karras (1996) on the US and European economies also suggest that real output is more sensitive to negative than to positive monetary shocks. Florio (2004) provides a survey of the asymmetry by distinguishing the output effects of negative and positive monetary policy shocks. In this study, we focus on the differential effects of monetary policy (measured by a 1 percentage-point increase of the interest rate) on output across regions and countries.
} 
Given this state of affairs, our study attempts to revisit and discuss some of the unresolved issues by providing a quantitative survey using a methodology known as metaanalysis. Meta-analysis constitutes a systematic approach towards analysing the sources of (quantitative) variation in previously obtained research results, and can therefore be useful in applied economic policy analysis (see Florax et al., 2002). In an earlier meta-analysis, De Grauwe and Storti (2004) examined the effects of monetary policies on real variables across countries, and found that methodological differences across studies significantly contribute to the variation of monetary impacts. Pitzel and Uuskula (2005), using only a small sample, conclude that monetary transmission in European countries is strongly influenced by financial depth and structure. ${ }^{4}$ Compared with those earlier studies, this paper extends their analyses in several ways. First, in order to deal with comparability issues, our sample is restricted to studies which employ Vector Autoregressive (VAR) models, and uniformly report the effects of a contractionary monetary shock (as measured by a 1 percentage-point increase of the interest rate) on output. Second, a broader set of conditioning variables has been introduced in order to find potential variables that can explain the variation of the output effects, and their selection is anchored in the existing theory. Finally, our study puts more emphasis on the output effects at a regional level rather than at a country level. ${ }^{5}$

The remainder of the paper is organized as follows. Section 2 briefly discusses the relevant theoretical background and typical monetary transmission channels. Section 3 introduces meta-analysis as a research tool, describes the structure of the meta-analysis sample, data and model specification. Section 4 describes the results of the meta-analysis identifying the role of study characteristics and other important factors that may explain the variation in the estimated effects of monetary policy on output. The final section concludes.

\section{Theoretical Background}

Conventional economic models have explained how monetary policy may influence the real economy through the aggregate demand side. The interest rate has long been known as the most prominent transmission channel. An increased interest rate leads to increases in the cost of capital. This in turn leads to a fall in the interest-sensitive components of aggregate

\footnotetext{
${ }^{4}$ Other related surveys were carried out by Cecchetti (1999) and Elbourne and de Haan (2004), using different research methods. The first author asserts that differences in legal systems have played a key-role in different monetary transmissions across European countries, while the latter found a small correlation between legal systems and financial structure that may cause the differences in monetary transmissions.

${ }_{5}^{5}$ Regions in this context are either narrowly defined regions, such as states or provinces under one sovereign country that share a national monetary policy or more broadly a collection of independent countries that are united under a monetary union, as in the eurozone.
} 
demand. An increase in short-term interest rates reduces the prices of assets, which in turn reduces consumption expenditure through wealth effects, and investment expenditure through Tobin's $q$-effects.

Another important channel through which a tightening of monetary policy tends to depress economic activity is the credit channel. In the credit view, the contractionary effects of monetary policy are transmitted to a large extent through lower bank lending. Also, the exchange rate channel of monetary policy is crucial, especially in small open economies. The monetary tightening causes the nominal exchange rate to appreciate. Assuming that nominal rigidities cause prices to be rather constant in the short run, an appreciation of the real exchange rate results. In turn, this may squeeze net exports (for further details, see, for example, Mishkin, 1995; 1996).

Meanwhile, some researchers alternatively have shown the importance of the supplyside or cost-side effects of monetary policy (see, for example, Bernanke and Blinder, 1992). An increase in the nominal interest rate may have an output effect primarily through an increase in production costs, notably via the working capital channel (for more details, see Barth III and Ramey, 2001). This may subsequently induce demand effects because of increasing prices.

Empirically, Vector Autoregressive (VAR) models have been widely used to study the transmission mechanism of monetary policy (see the surveys by Leeper et al., 1996, and Christiano et al., 1996). The VAR approach has several advantages. Since all the variables are treated symmetrically, there is no requirement to make a distinction between exogenous and endogenous variables (Sims, 1980, 1986; Bernanke, 1986). In a regional context, some analyses such as Carlino and DeFina $(1998,1999)$ and Fratantoni and Schuh (2003) adopt the VAR model to allow for spillover effects between regions. In principle, a VAR model consists of a set of equations in which each variable in the system is determined by its lagged values and the lags of all the other variables in the system. The VAR model in our case can be represented in the following moving-average representation (see, for example, Enders, 2004):

$$
B(L) y_{t}=u_{t}
$$

where $y_{t}$ is a $3 \times 1$ vector consisting of the log differences of the price level $(p)$, the output $(y)$, and the level of the short-term interest rate $(i) . B(L)$ is a polynomial in the lag operator described by a $3 \times 3$ matrix of coefficients. Shocks to the system, $\varepsilon_{t}{ }^{p}, \varepsilon_{t}{ }^{y}, \varepsilon_{t}^{i}$, are represented 
by the vector $u_{t}$. Then, $B(L)=I-B^{1} L^{1}-B^{2} L^{2}-\ldots B^{n} L^{n}$, where $n$ is the lag length of the VAR. One of the most relevant features of the VAR model is its impulse-response function which summarizes the dynamic interactions between variables (for example, between prices, output growth and the interest rate). As such, they capture history by describing the development over time of some relevant economic variables following a monetary policy shock (see Cochrane, 1998).

\section{Meta-analysis: method and descriptive analysis}

\subsection{The Method}

Meta-analysis as a tool for comparative study and research synthesis was first proposed by Glass (1976). It refers to the statistical analysis of a large collection of results from individual studies for the purpose of integrating the findings. Stanley and Jarrell (1989) characterize the method as 'the analysis of empirical analyses' that attempts to integrate and explain the literature about some specific important parameter. As later emphasized by Florax et al. (2002), meta-analysis provides the researcher with a toolkit to compare and/or combine outcomes of different studies with similar set-ups (or, alternatively, differences in set-ups that can be controlled for). As such, because of its statistical nature, it yields more objective and powerful estimates of the true effect size than other approaches such as narrative literature reviews or vote-counting reviews. As pointed out by Stanley (2004), the latter approach suffers from several problems such as methodological bias and questionable decisions or controversial results. And, finally, it can help to explain the abundant variation in empirical estimates often encountered in empirical research.

Initially meta-analysis was frequently used in the medical sciences. Nowadays it enjoys widespread use in many areas, including psychology, the social sciences, marketing, education and economics in particular. Stanley and Jarrell (1989) were the first to apply metaanalysis in economics, and later were rapidly followed by, for instance, Card and Krueger (1995) in labour economics, Smith and Huang (1995) in environmental economics, Nijkamp and Poot (2004) in macroeconomics of growth and fiscal policy, and Abreu et al. (2005) in the convergence literature. In macroeconomics and monetary economics in particular, several studies have attempted to apply meta-analysis to identify, for example, the effect of currency union membership on bilateral trade (Rose and Stanley, 2005), and the income elasticity of money demand (Knell and Stix, 2005). 


\subsection{Meta-Data and Explanatory Variables}

To collect empirical studies on the impact of monetary policy on regional economies relevant for our meta-analysis, we followed a standard approach and resorted to Econlit (the Economic Literature Index) that is widely known as a popular and easily accessible research database. ${ }^{6}$ Initially, the relevant studies were searched in this database, simply by typing the following keywords as any reference to: '(monetary policy*, or macroeconomic policy*), (output*, or growth*) and (region*, or country*)'. Subsequently, we checked all references in the studies gathered and added additional studies to the database based on a technique known as 'snowballing'. This resulted in a sample of 42 studies in total. Not all studies satisfied the criteria that we imposed. First, we restricted the sample to studies that used the vector autoregressive (VAR) model which gained momentum in the early 1990s. Previous studies relied on small structural models and reduced form equations (for example, Fishkind, 1977; Miller, 1978; Garrison and Chang, 1978). VAR offers a more reliable and modern econometric methodology with many advantages especially in dealing with endogeneity issues and the identification of shocks. Faust (1998) revealed the usefulness and robustness of the method for monetary issues in particular. Second, for reasons of comparability, we only included studies describing regional responses to a contractionary monetary policy shock in terms of the percentage output change due to a 1 percentage-point or 100 basis points interest rate increase. ${ }^{7}$ Using these selection criteria, we were left with a sample of 184 observations that were taken from 13 studies. $^{8}$ Most of our sample observations originate from well-known journals or publications. We have retained contributions from the "grey" literature to reduce the common concern of publication bias in meta-analytical studies.

The typical output effect in response to the monetary shocks based on the VAR model can best be summarized by an Impulse Response Function (IRF). As an illustration, in Figure 1 we show a hypothetical pattern of a time path of output effects based on the archetypical impulse response function (IRF) graphs found in our sample of studies. From the IRF graphs found in the studies, we derived four (related) effect-size measures that can be used to characterize the shape of the IRF. These effect-size measures are illustrated in Figure 1 and capture: (i) the output effect after four quarters $\left(y_{4}\right)$; (ii) the output effect after 16 quarters

\footnotetext{
${ }^{6}$ Visit http://www.econlit.org/

${ }^{7}$ The interest rate here in general refers to the central banks' short-term interest rate. The Fed rate is employed for the case of USA studies and the eurozone interest rate for the EMU (European Monetary Union) Member States. For other European countries that are not EMU members during the sample observation period, we employ the German call money rate as their reference policy rate.

${ }^{8}$ Studies included in the databases are indicated with a ' $\mathbf{} \mathbf{\prime}$ ' in the list of references.
} 
$\left(y_{16}\right)$; (iii) the maximum output effect $\left(y_{\max }\right)$; and (iv) the time it takes to arrive at the maximum effect $\left(t_{\max }\right){ }^{9}$

The maximum effect measures the peak (largest) impact of the monetary shock (in absolute terms) and refers to the lowest point of the curve. The fourth-quarter observation can be seen as a proxy measure for the short-run effect, while the sixteenth-quarter effect can be seen as representative for the medium-term effect. ${ }^{10}$ The time-estimate extracted may also be useful to illustrate the time it takes before the policy shock reaches its maximum impact (for more details, see Section 3.4). In the meta-regression analysis, all four effect-size types will be used as meta-dependent variables.

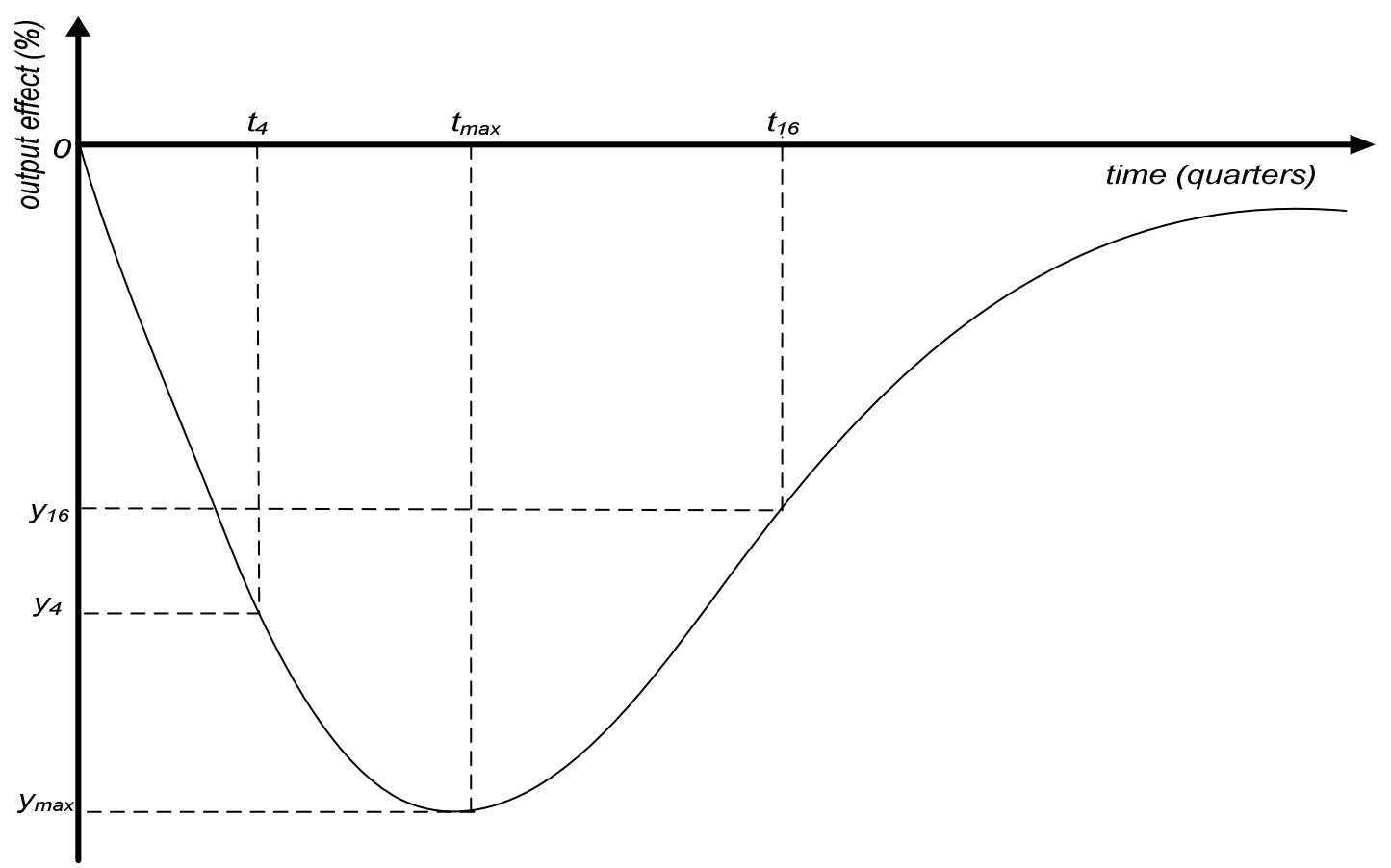

Figure 1. Characteristic pattern of the IRF graphs describing the size and timing of the output effects of monetary policy

The variables in the meta-analysis explaining the variation in our effect size measures can be categorized under 'primary study features' and 'conditioning variables'. They will be discussed in the remainder of this section. Under the primary study features, we can classify observations in our database according to:

\footnotetext{
${ }^{9}$ Since we had to recover these effect sizes from the IRF graphs, the graphs were enlarged to allow us to make the most accurate estimates.

${ }^{10}$ The sixteenth quarter is somewhat arbitrarily selected as a measure for the medium-run effect.
} 
- Type of model. The VAR model offers many flexibilities. To account for the resulting differences across studies, we distinguish between four different identifications schemes. The first is known as a recursive VAR model (Christiano et al., 1996). This scheme does not explicitly impose any structural restrictions from a particular economic theory, although it uses an ordering for all variables that is motivated by theory. The ordering itself is based on the Choleski decomposition, by putting the most endogenous variable in the last order. The second type of model utilizes non-recursive decomposition, and imposes that some variables can not contemporaneously affect each other. For example, a shock to the interest rate can have no contemporaneous effect on output (Sims, 1986; Bernanke, 1986). The third type of VAR model imposes long-run restrictions and is known as the AB-model. Applications of this methodology can, for instance, be found in Gali (1992). ${ }^{11}$ The two latter restrictions that more explicitly identify the effects of shocks based on a theoretical approach are known as Structural VARs (SVARs). Fourth, the dynamic specification of VAR also allows the use of a co-integrated model, where all the variables are difference stationary, while some linear combinations (co-integrated) of the variables are stationary (see, interalia, King et al., 1991). The latter model is also known as a co-integrated VAR or a vector error correction model (VECM). ${ }^{12}$ Following standard literature, we can label the last four models based on their specific restrictions as VAR-B, SVAR, SVAR-AB and VECM, respectively. ${ }^{13}$

- Model dimension. The dimension of a VAR is based on a number of endogenous variables in the system equation. Its introduction in our model is motivated by the fact that different models across studies use different dimensions in order to represent different economic structures and different reaction functions across countries and regions (Mihov, 2001). We take into account their differences across studies by assigning separate dummy variables. The first type is a standard dimension consisting of a three-variable system of output, prices, and interest rate. Another variant adds an exchange rate variable, and the last variant adds the output

\footnotetext{
${ }^{11}$ See Amisano and Giannini (1997).

12 For more details on restrictions and identifications in VAR models, see, for example, Lütkepohl (2007), Enders (2004) and Favero (2001).

${ }^{13}$ Here we only distinguish four different VAR models based on restriction types. Yet another type of VAR model imposes a long-run restriction à la Blanchard and Quah (1989). However, this type of restriction is not present in our sample, and hence we exclude it in our study.
} 
gap, commodity prices, real money, and foreign interest rate to the standard dimension.

- Data characteristics. We employ different dummy variables for observations that use different measures for the output effects of monetary policy. The output measures used depend on the geographical location of the studies. USA studies mainly employ State personal income, while European studies either use Gross Domestic Product (GDP) or the industrial production index (IPI). Variation of the short-term interest rates used, such as the central bank rate, or money market rate, will also be captured by a dummy variable.

- Temporal characteristics. Temporal variation across the sample of observations is taken into account and classified as follows. Following an eclectic approach, we have listed some measures that potentially represent the time dimension of the data: the midpoint of the sample period; the initial year of the sample; the end of period of the sample; the time-length of the sample period; and the dummy capturing the decade to which the study pertains (viz. the 1960s, 1970s, 1980s, and 1990s onwards). Meanwhile, we also take into account differences in time-lag length in our sample. Finally, the periodicity of the data used across studies (quarterly vs. monthly data) is distinguished by assigning a separate dummy variable.

The second group of explanatory variables in the meta-analysis contains conditioning variables. Basically, they are a set of control variables aimed at capturing other relevant factors consisting of macroeconomic and financial variables, as well as the characteristics of the geographical location: ${ }^{14}$

- Share of the manufacturing sector in GDP. This measure is commonly used to represent capital intensity (Schunk, 2005). Hence, it may be a good proxy to capture the economic structure of a particular region, in that it highlights the amount of capital utilized with respect to other production factors, such as labour. A number of studies assert that the measure may also represent sectoral (industrial) composition in an economy.

- Financial market variables. As predicted by theory, financial variables may affect variation in the strength of monetary transmission across geographical locations.

\footnotetext{
${ }^{14}$ The set of macroeconomic and financial variables are incorporated as explanatory variables (simultaneously with other variables) in our regression models, in order to shed light on why there are large variations in output effects across studies. The data-sources of these conditional variables are the World Development Indicators, the EU KLEMS database, the Bureau of Economic Analysis, and the OECD main economic indicators.
} 
Cecchetti (1999) employed several financial indicators to highlight the role of the financial structure in explaining differential monetary effects across European countries. Following his approach, this study employs the ratio of stock-market capitalization to GDP as a measure for the availability of alternative finance. Meanwhile, some other studies employ the level of financial development in explaining the variation in cross-country growth. Having reflected on this approach, in order to capture the variation of financial deepening across regions, we employ the number of bank offices (per 100,000 people), and the ratio of the credit to private enterprises over GDP. The latter indicator has been considered by King and Levine (1993) and Levine et al. (2000) as a measure of the level of financial development. ${ }^{15}$ Following these studies, we use private credit as our preferred measure of financial development. This is the value of credit by financial intermediaries to the private sector, divided by GDP. This type of credit is the preferred measure because it excludes credit granted to the public sector and credit granted by the central banks and other government banks.

- Inflation rate. This measure is considered because the major central banks around the world tend to pursue price stability as a primary goal of their monetary policy. Price stability is desirable because a high inflation rate creates uncertainty in the economy, and that may hamper economic growth. Given the negative relationship between inflation and growth, Fischer (1996) highlights the importance of central banks viewing the control of inflation as their ultimate goal. De Grauwe and Storti (2004) have also employed this measure based on Lucas's island model (1972) which basically posits that the aggregate supply is a function of the relative variance of real and nominal disturbances.

- Economic size. This measure is based on gross regional domestic product (GRDP) or gross domestic product (GDP) in US dollars. An alternative measure for size is the number of inhabitants. A final dimension that we will control for is G(R)DP per capita to capture the potential effect of differences in the stage of development.

- Share of exports in goods and services in total $G(R) D P$. This measure is commonly used to represent the degree of openness of a particular country or region. Several studies have discussed how differences in openness could be important in

\footnotetext{
${ }^{15}$ Because of data availability at the regional level, we could not include all the variables to capture the financial structure used by Cecchetti (1999). Different concepts for small bank loans and firm size between the USA and the European countries also pose limitations in employing them as explanatory variables.
} 
explaining regional variation in the response to monetary policy shocks. Consider the impact of monetary tightening which would result in a general slowdown of domestic activity, although regions that earn a large part of their revenues from overseas would experience some protection against direct interest rate effects. Therefore, a region that is relatively more export-oriented is less likely to be affected by interest rate shocks, and vice versa.

- Geographical characteristics. We consider studies on both regions and countries and will use a dummy variable to distinguish the two groups. A further distinction will be made between countries being a member of a monetary union and independent countries.

\subsection{Descriptive Statistics}

Before turning to the meta-regression analysis, we briefly discuss some descriptive statistics of our four different effect-size measures which capture the size and time dimension of the effects (see Figure 1). As mentioned before, they are obtained from the IRFs of the primary studies, and characterize the path of output following a contractionary monetary policy. In general, the sample of observations recovered from the studies tends to show a large variation of the estimated output elasticity.

Figures $2 \mathrm{a}-2 \mathrm{c}$ show the output effects of a contractionary monetary policy at the maximum level, the fourth quarter, and the sixteenth quarter, respectively. In the first figure, the mean of the maximum impact is 0.76 per cent, so a one-percentage point increase of interest rate will on average be followed by 0.76 per cent maximum output decrease. The sixteenth quarter measure is a proxy for the medium-term effect and equals around 0.50 per cent. Figure $2 \mathrm{c}$ represents the fourth quarter effect (viz. the short-term effect). The mean output decline is equal to 0.31 per cent. All three average effect sizes are statistically significantly different from zero. Finally, Figure $2 \mathrm{~d}$ depicts that the time elapsed (in quarters) to reach the maximum effect in response to the shock, which has a mean of about 8 quarters (two years). More details of the descriptive statistics of these four measures can be found in Appendix A. 


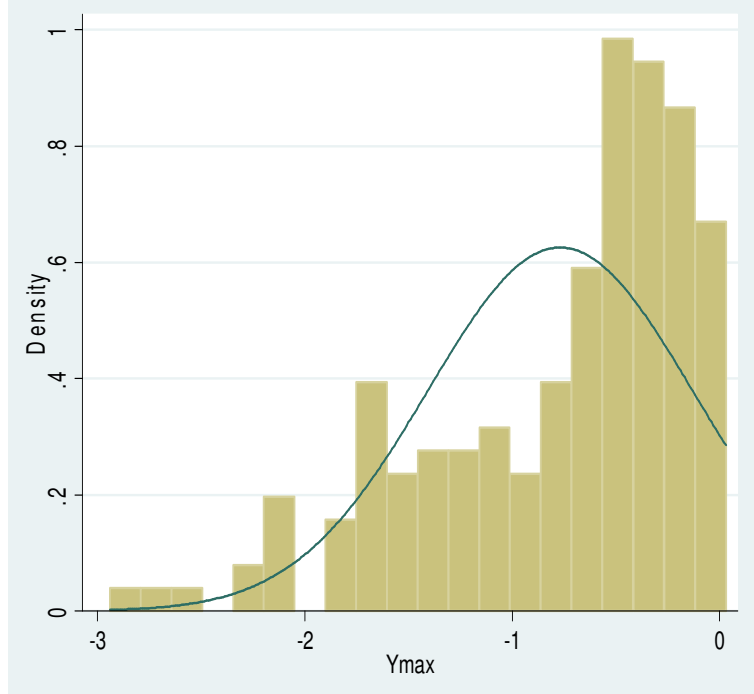

Figure 2a. Histogram of the maximum output effect in response to a 1 percentage-point increase of the interest rate $\left(y_{\max }\right)$

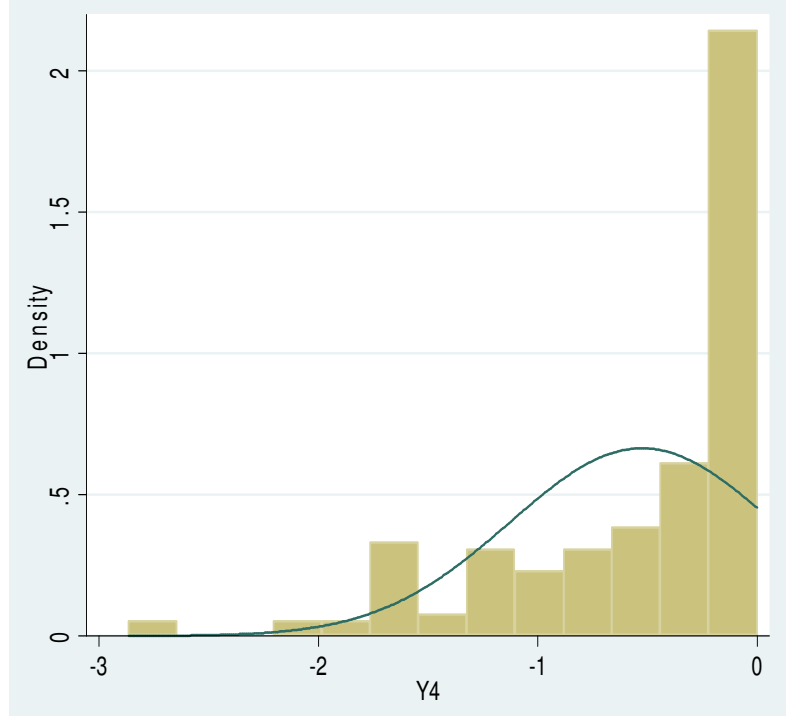

Figure 2c. Histogram of the output effect in the fourth quarter in response to a 1 percentage-point increase of the interest rate $\left(y_{4}\right)$

Figure 2. Distribution of effect sizes

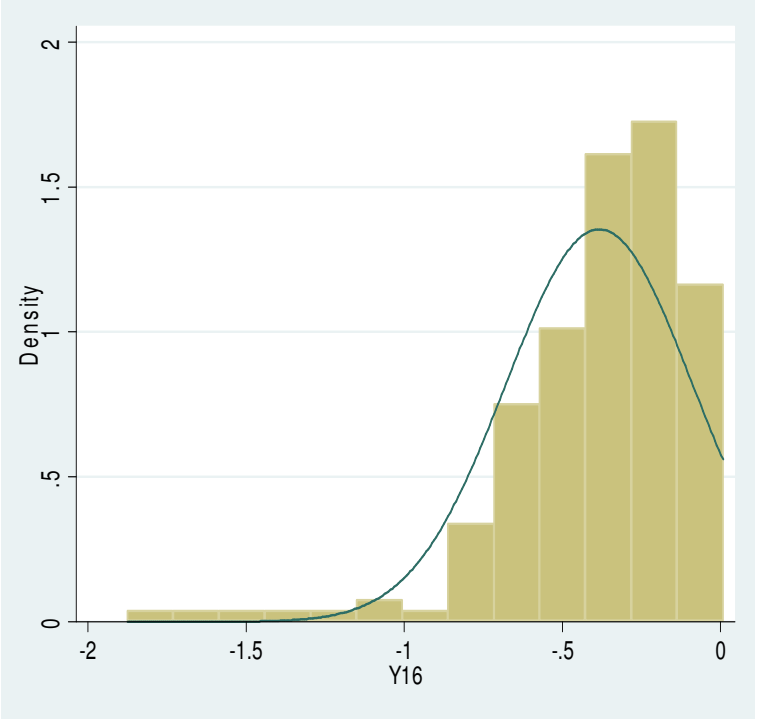

Figure 2b. Histogram of the output effect in the sixteenth quarter in response to a 1 percentagepoint increase of the interest rate $\left(y_{16}\right)$

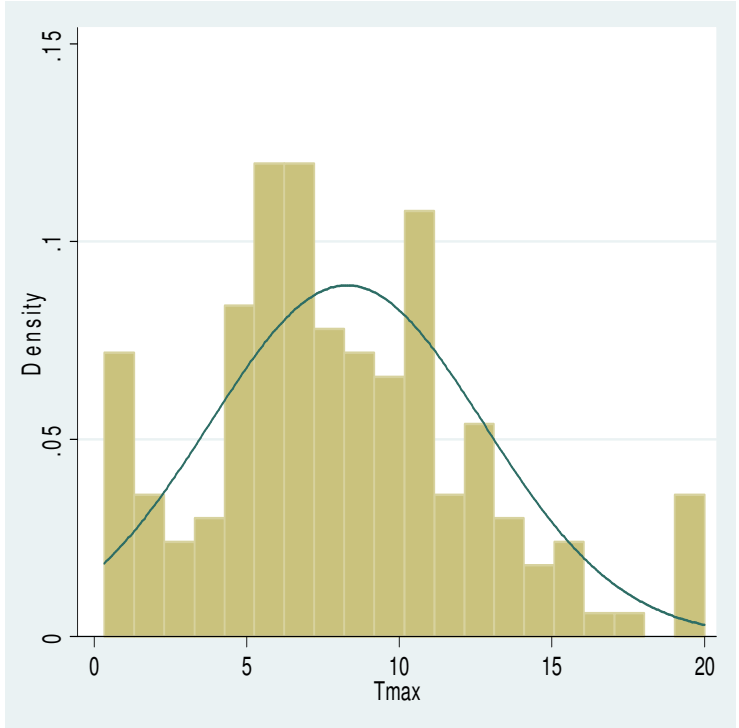

Figure $2 d$. Histogram of time elapsed at the maximum effect (in quarters) of the policy shock $\left(t_{\max }\right)$

\section{Meta-Regression Analysis}

\subsection{Meta-Regression Model}

The general specification of our meta-regression model is as follows:

$$
Y_{j}=\alpha+\sum \beta_{i} X_{i j}+\varepsilon_{j}, i=1,2, \ldots, K ; j=1,2, \ldots \ldots, L,
$$


where $Y_{j}$ represents the effect size of interest (indexed $j$ ). For each observation, we consider four different effect sizes: namely, the maximum output effect; the fourth quarter output effect; the sixteenth quarter output effect; and the time-elapsed at the maximum. Earlier we have discussed two sets of explanatory variables $\left(X_{i j}\right)$, referring to study-characteristics and conditioning variables. $\alpha$ and $\beta$ are parameters to be estimated, and $\varepsilon$ is the error term. Details on the explanatory variables can be found in Appendix A.

In our basic model specification, we estimate the model using standard OLS. A characteristic problem for meta-analyses is that OLS standard errors may be inconsistent due to the presence of region/country-specific heteroscedasticity or region/country-pair-specific contemporaneous correlation of the errors. We therefore employ robust Huber-White standard errors in order to correct simultaneously for the heteroscedasticity and cluster autocorrelation. ${ }^{16}$ This correction leaves the OLS estimates of the coefficient of interest unaffected, but yields consistent standard errors.

\subsection{Empirical Results}

In presenting the results of our meta-regression, we will assess the relative importance of moderator variables by means of inferential tests of statistical significance. Additionally, we will also evaluate their economic significance (cf. Ziliak and McCloskey, 2004). The results are presented in Sections 4.2.1 and 4.2.2, respectively.

\subsubsection{Statistical Significance}

Capital intensity - As seen in Table 1, the coefficients of the share of the manufacturing sector in GDP denote a positive (in absolute terms) and significant impact in the maximum model, the fourth quarter model, and the sixteenth quarter model. ${ }^{17} \mathrm{~A} 1$ percentage-point increase in the interest rate leads to an output reduction by about 0.03 percentage-points, 0.01 percentage-points, and 0.04 percentage-points, respectively. Hence, these results suggest the importance of capital intensity in explaining the variation of the output effects.

\footnotetext{
${ }^{16}$ Cluster autocorrelation refers to the situation where observations are independent across clusters (studies), but not necessarily independent within clusters. See Gorg and Strobl (2001) and Abreu et al. (2005) for applications of the Huber-White sandwich estimator in the context of meta-analysis.

${ }^{17}$ There is robust evidence to suggest that manufacturing industries are highly sensitive to interest rates.
} 
Table 1. Meta-regression estimates based on the OLS robust standard errors

\begin{tabular}{|c|c|c|c|c|}
\hline \multirow[b]{2}{*}{ Explanatory variables: } & \multicolumn{4}{|c|}{ Dependent variables } \\
\hline & $\begin{array}{l}\text { Maximum effect } \\
\text { (\%-point) }\end{array}$ & $\begin{array}{l}\text { The fourth } \\
\text { quarter effect } \\
\text { (\%-point) }\end{array}$ & $\begin{array}{c}\text { The sixteenth } \\
\text { quarter effect (\%- } \\
\text { point) }\end{array}$ & $\begin{array}{c}\text { Time elapsed at } \\
\text { maximum effect (in } \\
\text { quarters) }\end{array}$ \\
\hline Manufacturing sector (as a $\%$ of GDP) & $\begin{array}{l}-0.031^{* *} \\
(3.17)\end{array}$ & $\begin{array}{l}-0.014^{* *} \\
(2.78)\end{array}$ & $\begin{array}{l}-0.037^{* * *} \\
(4.10)\end{array}$ & $\begin{array}{c}0.067 \\
(1.16)\end{array}$ \\
\hline Stock-market (as a \% of GDP) & $\begin{array}{l}0.004^{*} \\
(2.36)\end{array}$ & $\begin{array}{l}0.002^{* *} \\
(3.18)\end{array}$ & $\begin{array}{r}-0.003 \\
(1.30)\end{array}$ & $\begin{array}{c}0.029 \\
(1.53)\end{array}$ \\
\hline Inflation rate & $\begin{array}{l}0.001^{*} \\
(2.17)\end{array}$ & $\begin{array}{c}-0.003 \\
(0.46)\end{array}$ & $\begin{array}{c}0.005 \\
(1.52)\end{array}$ & $\begin{array}{c}-0.029 \\
(0.77)\end{array}$ \\
\hline Size of GDP & $\begin{array}{l}0.105^{* *} \\
(2.66)\end{array}$ & $\begin{array}{l}0.004 \\
(0.20)\end{array}$ & $\begin{array}{l}0.158^{* * *} \\
(4.35)\end{array}$ & $\begin{array}{l}-0.938^{* * * *} \\
(3.71)\end{array}$ \\
\hline Exports (as a \% of GDP) & $\begin{array}{r}0.003 \\
(0.75)\end{array}$ & $\begin{array}{r}0.001 \\
(0.02)\end{array}$ & $\begin{array}{l}0.008^{* *} \\
(2.75)\end{array}$ & $\begin{array}{l}-0.058 \\
(1.79)\end{array}$ \\
\hline Regional dummy & $\begin{array}{r}-0.269 \\
(1.02)\end{array}$ & $\begin{array}{c}-0.203 \\
(1.30)\end{array}$ & $\begin{array}{r}0.039 \\
(0.17)\end{array}$ & $\begin{array}{c}-2.703 \\
(1.48)\end{array}$ \\
\hline Midpoint of observation period & $\begin{array}{r}0.059 \\
(0.76)\end{array}$ & $\begin{array}{l}0.051 \\
(1.24)\end{array}$ & $\begin{array}{l}0.183^{* *} \\
(2.62)\end{array}$ & $\begin{array}{c}-1.223^{*} \\
(2.15)\end{array}$ \\
\hline Model dummy (VAR-B) & $\begin{array}{l}0.205 \\
(1.72)\end{array}$ & $\begin{array}{r}0.131 \\
(1.71)\end{array}$ & $\begin{array}{c}0.082 \\
(0.74)\end{array}$ & $\begin{array}{c}1.408 \\
(1.02)\end{array}$ \\
\hline Model dummy (SVAR) & $\begin{array}{r}-0.177 \\
(1.01)\end{array}$ & $\begin{array}{l}0.107 \\
(0.92)\end{array}$ & $\begin{array}{c}-0.192 \\
(1.44)\end{array}$ & $\begin{array}{l}1.721 \\
(1.28)\end{array}$ \\
\hline Model dummy (SVAR-AB) & $\begin{array}{r}0.219 \\
(1.38)\end{array}$ & $\begin{array}{l}0.195^{*} \\
(2.42)\end{array}$ & $\begin{array}{c}0.126 \\
(0.87)\end{array}$ & $\begin{array}{l}1.740 \\
(1.04)\end{array}$ \\
\hline Quarterly data dummy & $\begin{array}{c}0.057 \\
(0.30)\end{array}$ & $\begin{array}{l}0.041 \\
(0.35)\end{array}$ & $\begin{array}{l}-0.021 \\
(0.15)\end{array}$ & $\begin{array}{l}2.815^{*} \\
(2.21)\end{array}$ \\
\hline Constant & $\begin{array}{l}-2.139^{*} \\
(2.37)\end{array}$ & $\begin{array}{c}-0.183 \\
(0.36)\end{array}$ & $\begin{array}{l}-2.488^{* *} \\
(3.13)\end{array}$ & $\begin{array}{l}21.64^{* * *} \\
(3.91)\end{array}$ \\
\hline $\begin{array}{l}N \\
\text { Adj } R^{2}\end{array}$ & $\begin{array}{c}170 \\
0.185\end{array}$ & $\begin{array}{c}184 \\
0.071\end{array}$ & $\begin{array}{c}178 \\
0.288\end{array}$ & $\begin{array}{c}169 \\
0.305\end{array}$ \\
\hline
\end{tabular}

Notes: Absolute robust $t$-statistics in parentheses. Asterisks indicate statistical significance: ${ }^{*}$ significant at the $10 \%$ level; ${ }^{* *}$ significant at the $5 \%$ level; ${ }^{* * *}$ significant at the $1 \%$ level.

Capital-intensive sectors turn out to be sensitive to the change of interest rate. This may be explained as follows. First, it relates to the cost channel or supply side. An increase of the interest rate will be followed by rise of production costs in the industrial sector, while its demand may respond in the opposite direction (demand side effect) resulting in a decline in output (see Section 2). ${ }^{18}$ Second, an increase in the interest rate reduces demand for

\footnotetext{
${ }^{18}$ It is necessary to bear in mind that, within this line of thinking, the concept of non-neutrality of money may prevail due to some type of rigidity.
} 
investment goods and (durable) consumer goods. ${ }^{19}$ When industries differ in their sensitivity to changes in the interest rate and regions differ in industrial composition, this may explain how a uniform monetary policy may generate differential regional effects. Carlino and DeFina (1998, 1999) and Hayo and Uhlenbrock (1999) found that the industry mix has played a key role in determining the heterogeneous effects of the policy response across the US States, and German regions, respectively. ${ }^{20}$

Financial market variables - Capital market capitalization as a percentage of GDP as our measure in examining the variation in financial deepening is found to be negative (in absolute terms) and statistically significant, particularly in the maximum and the fourth quarter effect model. ${ }^{21}$ This may relate to differences in the regions' stage of financial development. A peripheral region which is more dependent on banks is likely to be more adversely affected if interest rates rise following monetary policy contractions. In the meantime, a core region which has access to capital markets as alternative financial sources may be less affected once monetary policy is tightened.

Inflation rate - The coefficient of the rate of inflation is also statistically significant, with a negative sign, particularly in the maximum effect model. As discussed in Section 3, the finding tends to be consistent with the previous presumption that an economy with higher price rigidity may be less affected by monetary policy changes than a less rigid one. Therefore, a stronger policy push is required to facilitate growth and employment in a highinflation region.

Economic size - Coefficients of the economic size tend to indicate significant results, with a negative sign, particularly in the maximum and the sixteenth quarters (medium-term) model. In these models, a 1 percentage-point increase in the interest rate leads to reduction of output by 0.11 percentage points and 0.16 percentage points, respectively. As the direction (sign) turns out to be negative (in absolute terms), small economies turn out to be more adversely

\footnotetext{
${ }^{19}$ Several studies reveal that durable-goods industries, such as investment goods, tend to be more responsive to monetary policy changes relative to the non-durable ones such as food (see, for example, Barth III and Ramey, 2001; Ganley and Salmon, 1997; Dedola and Lippi, 2000).

${ }^{20}$ As an illustration, an interest-sensitive sector, i.e. manufacturing, accounted for 27 per cent of real gross state product (GSP) in the Great Lakes region, on average, during the 1985-1990 period, but less than 13 per cent of the Rocky Mountains region's real GSP (see Carlino and DeFina, 1999).

${ }^{21}$ We have used alternative proxies to evaluate financial development by employing the share of credit to GDP and the number of bank offices per 100,000 people. However, both of these are statistically insignificant. This result is not shown, but is available upon request.
} 
hit by a national (interest rate) shock than large economies. This can be explained as follows. First, in order to reap gains from global trade, small economies might specialize more strongly specific industries. This specialization can make economies more vulnerable to monetary shocks (Kalemli-Ozcan et al., 2001). In addition, political economy arguments can also be relevant. Second, small economies may generally face larger shock impacts (output loss) relative to the larger economies, particularly related to their lower degree of resilience to the shock. ${ }^{22}$ Third, at the national level, large countries tend to have larger capacities in distributing resources from richer to poorer regions (see, for example, Alesina et al., 2005). In their study, De Grauwe and Storti (2004) do not find a statistically significant effect of economic size, so they conclude that there is no differential output effect between small and large countries. Ehrmann (1998), on the other hand, detects a substantial heterogeneity in the magnitude of the output effects across the European countries, with small effects in small economies, as opposed to large effects in large ones.

Degree of openness - On the basis of our regression model, export (in terms of goods and services) as a percentage of GDP has no statistically significant effect in determining differential monetary policy effects both in output size and time-speed. ${ }^{23}$ Using a similar approach, Dedola and Lippi (2005) and Peersman and Smets (2005) also failed to find any statistically significant evidence that the degree of openness was a factor in explaining heterogeneous responses. A possible explanation for this result might be that this measure only indirectly captures the degree of openness, particularly in the monetary (financial) area. Consequently, we ought to consider other types of openness measures that could directly capture cross-border financial transactions, and thus would be better able to examine the links between the degree of openness and the monetary policy shocks. ${ }^{24}$ This issue is left for further research.

\footnotetext{
${ }^{22}$ Several studies indicate that small economies may have some economic system limitations in dealing with economic shocks: namely, the low level of savings, lack of institutional set-ups, larger fiscal constraints, supplyside bottlenecks, and more dependence on external economies (foreign investment). On the other hand, larger economies tend to have a stronger capacity and more flexible mechanisms to cope with the shock.

${ }^{23}$ Only a weak significant effect is found in the sixteenth quarter model.

${ }^{24}$ While our study focuses on the role of the interest rate as a prominent channel of monetary policy, the existing literature also posits that the exchange rate channel may play a key role in determining the variation of policy effects. The higher relative interest rate induces a capital inflow, which causes the exchange rate to appreciate, and this in turn results in a loss of competitiveness and, thus, a decline in the demand for exports. Taking this impact on competitiveness via external demand into account suggests that regions with export- intensive sectors would be more sensitive to monetary policy changes. Therefore, further separate investigation is needed to see whether the exchange rate channel is able to capture this external effect.
} 
Midpoint of the observation period - This variable in general turns out to be not significant in most of the size-effect regressions. The result may indicate that there is only weak evidence of a long run trend in the output effect, particularly in the maximum and fourth quarter effect, albeit the trend is found to be significant (and positive) in the sixteenth quarter effect. Meanwhile, we find that there is a tendency for shortening, i.e. an acceleration process, in the time taken to reach the full effects of policy shocks. The role of technological progress, which is mainly due to the rapid development of the Information and Communication Technologies (ICTs) in the last two decades, could be a key-factor in speeding up the ripple effect of monetary shocks across regions and countries within a monetary union.

Considering study characteristics, Table 1 shows that type of model used (based on specific identification and restriction) in primary studies tends to be significant in explaining heterogeneities across studies, particularly for SVAR-AB. The salient feature of this identification scheme is that it is based on a structural form which distinguishes between the short-run and the long-run effect of shocks. ${ }^{25}$

Finally, variation in time-frequency data is only able to explain variation in the output effect when the 'time elapsed' indicator is used. Note that apart from the difference in measurement frequency there is another difference: monthly data typically measure industrial production whereas quarterly data relate to GDP. The latter indicator covers a much larger scope of economic activity both in terms of production and demand.

\subsubsection{Economic significance}

There are various ways to illustrate the economic significance of the effects that are presented in Table 1. A simple way is to consider the difference in the effect size between two hypothetical regions for which the difference in their score on the explanatory variable is equal to four standard deviations (SDs). ${ }^{26}$ An overview of the results is given in Table 2.

\footnotetext{
${ }^{25}$ Ehrmann (2000) posits that the SVAR has congruency advantage, i.e. the accordance of a model with all the available evidence from all possible sources. This allows SVAR to have free systematic patterns in error terms, and a well-specified model can be established.

${ }^{26}$ This is approximately equal to the difference in the effect size between a country that is at 97.5 per cent in the cumulative distribution of the explanatory variable and a country that is at 2.5 per cent. Alternatives are, for example, to compare a country with the maximum score on the explanatory variables with a country with the minimum score. Please note that all dependent variables (except for the timing effect) have a negative sign. Consequently, the interpretation of the results will be in absolute terms.
} 
Capital intensity - Considering the importance of the share of manufacturing, we see that the differential impact on the maximum output effect between two hypothetical regions that differ by four SDs in manufacturing as a percentage of GDP is equal to 1.08 per cent (relative to a mean effect of 0.77 per cent). ${ }^{27}$ Therefore, following a 1 percentage-point increase of the interest rate the output loss for these two hypothetical regions/countries (centered around the mean) ranges from 0.23 to 1.32 per cent in a capital-extensive region and a capital-intensive region, respectively.

Likewise, the differential impact of four SDs difference between the two regions on the fourth quarter effect is equal to 0.48 per cent, and hence the impact of the monetary actions will reduce the output of the two regions by between 0.10 and 0.58 per cent, respectively. The sixteenth quarter effect indicates the highest difference by about 1.29 per cent compared with the other two effects, and the output effect of the two regions is between -1.17 per cent and 0.12 per cent. The results of the three effects confirm that regional differences in the capitalintensive sector lead to significant variation in interest rate sensitivity.

The speed of the shocks (measured by the time elapsed to reach the maximum effect) that differs in the two regions by four SDs in manufacturing (as a percentage of GDP) is equal to 2.36 quarters (relative to a mean effect of 8.28). In other words, the time elapsed at the maximum effect is between 7.11 quarters in a capital-extensive region and 9.45 quarters in a capital-intensive region. Therefore, the first region reaches the peak of the policy shock considerably faster than the second region.

Financial market variable - Following the previous approach, the differential impact on the maximum effect between two regions that differ by four SDs in stock-market capitalizations (as a percentage of GDP) is equal to 0.46 per cent. Thereby, output decline in a region with a more developed financial market will be lower relative to the less developed market following monetary actions within a range of 0.55 and 1.00 per cent. Meanwhile, as a difference of four SDs in stock-market capitalization (as a percentage of GDP) is equivalent to 3.39 quarters, likewise it suggests that the time elapsed to reach the maximum effects would be shorter in less developed market by about 6.59 quarters than in the developed market, where it is 9.98 quarters.

Inflation rate - The differential impact on the maximum effect between two regions that have a four-SD difference in their inflation rate is equal to 0.39 per cent. Hence, the regional

\footnotetext{
${ }^{27}$ See Appendix A for descriptive statistics of the variables.
} 
output effects of monetary policy will decline within a range of 0.58 per cent in a high inflation economy and 0.97 per cent in a low economy. The regional differences in the time elapsed at maximum effect (with a four-SD difference) is equal to -1.14 quarters. A high inflation economy has a prolonged effect in time-adjustment by about 8.86 quarters relative to the low inflation economy, where it is 7.71 quarters in order to reach the full effects of monetary policy.

Economic size - The impact variation on the maximum effect between two regions that differ in economic size (with a four SD-difference) is equal to 0.58 per cent. A large size economy tends to have smaller output reduction by about 0.49 per cent than a small economy, where it is 1.06 per cent following a monetary innovation. As previously, here we can see even more clearly that large economies tend to be less affected by the common policy shocks than small economies.

\subsection{Accounting for Quality of Observations}

So far, we have treated all observations with equal weight. Standard procedures in metaanalysis to weight observations with their standard errors (as a measure for the precision with which they have been estimated) are not feasible in this case because standard errors are not available. Nevertheless, in order to still exploit some information on the 'quality of the observations', we will use different weighting schemes capturing certain dimensions of quality by estimating weighted (generalized) least squares regression equations (see Gujarati, 2003; Greene, 2008). ${ }^{28}$

Having assigned the different weights, we may check the robustness and reliability of our meta-regression results. In doing so, we then recalculate our results from Table 1 (as the benchmark) by using various weighting schemes. First, we assign weights to the observations based on journal rankings reported in Kalaitzidakis et al. (2003). Second, we assign the square root of the degrees of freedom as an alternative weight to explain the precision of the estimates. $^{29}$ The robustness of our regression results can be inferred from the extent of the consistency in estimated coefficients across different specifications.

\footnotetext{
${ }^{28}$ The use of weights in meta-analysis is not undisputed. Weichselbaumer and Winter-Ebmer (2005) and Knell and Stix (2005) provide some discussion and applications of how meta-regressions could be weighted. In contrast, Krueger (2003) rejects weighting studies by, for example, the number of estimates, and instead proposes equal weighting as the more appropriate approach.

${ }^{29}$ Based on sampling theory, the value of the $t$-statistic is proportional to the square root of the degrees of freedom in the regression.
} 
As shown in Table 3, the results for the four effect sizes remain unaltered compared with the benchmark regression in terms of sign, significance, and size. Specifically, the main explanatory variables such as capital intensity, financial structure, inflation rate, economic size, time period, and type of model, all tend to be significant. Assigning an alternative weight, notably degrees of freedom and sample-size, does not strongly affect the initial results. Therefore, taking these findings all together we may conclude that the benchmark regression tends to be robust. 
Table 2. Economic significance of determinants of output effects according to the meta-regression

\begin{tabular}{|c|c|c|c|c|c|c|c|c|c|c|c|c|}
\hline \multirow{4}{*}{ Explanatory variables } & \multicolumn{12}{|c|}{ Dependent variables } \\
\hline & \multicolumn{3}{|c|}{$\begin{array}{l}\text { Maximum effect } \\
(\%)\end{array}$} & \multicolumn{3}{|c|}{$\begin{array}{l}\text { The fourth quarter effect } \\
\qquad(\%)\end{array}$} & \multicolumn{3}{|c|}{$\begin{array}{c}\text { The sixteenth quarter effect } \\
(\%)\end{array}$} & \multicolumn{3}{|c|}{$\begin{array}{l}\text { Time-elapsed at maximum } \\
\text { effect (in quarters) }\end{array}$} \\
\hline & \multirow[t]{2}{*}{$4 \mathrm{SD}$} & \multicolumn{2}{|c|}{ Bandwidth } & \multirow[t]{2}{*}{$4 \mathrm{SD}$} & \multicolumn{2}{|c|}{ Bandwidth } & \multirow[t]{2}{*}{$4 \mathrm{SD}$} & \multicolumn{2}{|c|}{ Bandwidth } & \multirow[t]{2}{*}{$4 \mathrm{SD}$} & \multicolumn{2}{|c|}{ Bandwidth } \\
\hline & & Lower & Upper & & Lower & Upper & & Lower & Upper & & Lower & Upper \\
\hline Manufacturing sector (\% of GDP) & -1.08 & -1.32 & -0.23 & -0.48 & -0.58 & -0.10 & -1.29 & -1.17 & 0.12 & 2.36 & 7.11 & 9.46 \\
\hline Stock-market capitalization ( $\%$ of GDP) & 0.46 & -1.00 & -0.55 & 0.28 & -0.48 & -0.20 & -0.32 & -0.68 & -0.37 & 3.39 & 6.59 & 9.98 \\
\hline Inflation rate & 0.39 & -0.97 & -0.58 & -0.11 & -0.40 & -0.28 & 0.19 & -0.62 & -0.43 & -1.14 & 7.71 & 8.86 \\
\hline Size of GDP & 0.58 & -1.06 & -0.49 & 0.02 & -0.35 & -0.33 & 0.86 & -0.96 & -0.09 & -5.13 & 5.72 & 10.85 \\
\hline Exports (\% of GDP) & 0.22 & -0.88 & -0.66 & 0.00 & -0.34 & -0.34 & 0.04 & -0.55 & -0.50 & -0.32 & 8.12 & 8.44 \\
\hline Regional dummy & -0.54 & -1.04 & -0.51 & -0.40 & -0.54 & -0.14 & 0.08 & -0.56 & -0.49 & -5.37 & 5.60 & 10.97 \\
\hline Midpoint of observation period & 0.24 & -0.89 & -0.65 & 0.21 & -0.44 & -0.24 & 0.73 & -0.89 & -0.16 & -4.89 & 5.84 & 10.73 \\
\hline Model dummy (VAR-B) & 0.36 & -0.95 & -0.60 & 0.23 & -0.45 & -0.23 & 0.14 & -0.60 & -0.45 & 2.44 & 7.06 & 9.50 \\
\hline Model dummy (SVAR) & -0.24 & -0.89 & -0.65 & 0.14 & -0.41 & -0.27 & -0.26 & -0.65 & -0.40 & 2.32 & 7.12 & 9.44 \\
\hline Model dummy (SVAR-AB) & 0.31 & -0.93 & -0.62 & 0.27 & -0.48 & -0.20 & 0.18 & -0.61 & -0.44 & 2.43 & 7.07 & 9.50 \\
\hline Quarterly data dummy & 0.08 & -0.81 & -0.73 & 0.06 & -0.37 & -0.31 & -0.03 & -0.54 & -0.51 & 4.10 & 6.23 & 10.34 \\
\hline
\end{tabular}


Table 3. Meta-regression results using different weighting schemes

Dependent Variables

Explanatory variables

Maximum effect The fourth quarter effect The sixteenth quarter effect Time elapsed at maximum

\begin{tabular}{|c|c|c|c|c|c|c|c|c|}
\hline & \multicolumn{2}{|c|}{$(\%)$} & \multicolumn{2}{|c|}{$(\%)$} & \multicolumn{2}{|c|}{$(\%)$} & \multicolumn{2}{|c|}{ (quarters) } \\
\hline & $(1)$ & (2) & $(1)$ & $(2)$ & (1) & $(2)$ & $(1)$ & $(2)$ \\
\hline \multirow{2}{*}{ Manufacturing sector (as a \% of GDP) } & -0.016 & $-0.028^{* *}$ & -0.007 & $-0.013^{* *}$ & $-0.023^{* *}$ & $-0.032^{* * *}$ & 0.046 & 0.092 \\
\hline & $(1.82)$ & $(3.25)$ & $(1.40)$ & $(2.70)$ & $(2.76)$ & $(4.28)$ & $(0.81)$ & $(1.33)$ \\
\hline \multirow{2}{*}{ Stock-market capitalizations (as a \% of GDP) } & 0.001 & 0.004 & 0.002 & $0.003^{*}$ & $-0.005^{*}$ & -0.003 & $0.039^{*}$ & $0.031^{*}$ \\
\hline & $(0.54)$ & $(1.63)$ & $(1.33)$ & $(2.41)$ & $(2.44)$ & $(1.85)$ & $(2.54)$ & $(2.50)$ \\
\hline \multirow[t]{2}{*}{ Inflation rate } & $0.013^{* *}$ & 0.011 & $-0.008^{* * *}$ & 0.001 & 0.005 & 0.006 & -0.061 & -0.017 \\
\hline & (2.99) & $(1.88)$ & $(3.44)$ & $(0.10)$ & $(1.32)$ & $(1.21)$ & $(1.52)$ & $(0.53)$ \\
\hline \multirow[t]{2}{*}{ Size of GDP } & 0.068 & 0.082 & -0.030 & -0.007 & $0.140^{* * *}$ & $0.154^{* * *}$ & $-0.858^{* *}$ & -0.418 \\
\hline & $(1.67)$ & $(1.91)$ & $(1.30)$ & $(0.29)$ & $(3.53)$ & $(4.18)$ & $(3.00)$ & $(1.22)$ \\
\hline \multirow[t]{2}{*}{ Exports (as a \% of GDP) } & 0.006 & 0.002 & 0.002 & -0.001 & $0.011^{* *}$ & $0.008^{*}$ & $-0.060^{*}$ & -0.053 \\
\hline & $(1.62)$ & $(0.41)$ & $(1.07)$ & $(0.29)$ & $(3.05)$ & $(2.27)$ & $(2.11)$ & $(1.82)$ \\
\hline \multirow[t]{2}{*}{ Regional dummy } & $0.179^{*}$ & 0.069 & $0.156^{* * *}$ & 0.057 & $0.199^{* *}$ & $0.183^{*}$ & $-1.391^{*}$ & -0.685 \\
\hline & $(2.40)$ & $(0.80)$ & (3.97) & $(1.19)$ & $(2.92)$ & $(2.48)$ & $(2.41)$ & $(1.32)$ \\
\hline \multirow[t]{2}{*}{ Midpoint of observation period } & 0.535 & -0.190 & 0.189 & -0.200 & $0.526^{*}$ & 0.179 & $-4.886^{* *}$ & -2.189 \\
\hline & $(1.87)$ & $(0.74)$ & $(1.29)$ & $(1.41)$ & $(2.07)$ & $(0.82)$ & $(2.83)$ & $(1.28)$ \\
\hline \multirow[t]{2}{*}{ Model dummy (VAR-B) } & 0.104 & 0.193 & $0.255^{* *}$ & $0.180^{*}$ & $-0.341^{*}$ & 0.036 & $2.786^{*}$ & 1.626 \\
\hline & $(0.63)$ & $(1.15)$ & $(2.99)$ & $(2.10)$ & $(2.31)$ & $(0.28)$ & $(2.47)$ & $(1.35)$ \\
\hline \multirow[t]{2}{*}{ Model dummy (SVAR) } & -0.233 & -0.239 & $0.230^{* *}$ & 0.146 & -0.255 & -0.264 & $3.690^{* *}$ & 1.296 \\
\hline & $(1.43)$ & $(1.35)$ & $(2.64)$ & $(1.58)$ & $(1.69)$ & $(1.86)$ & $(3.12)$ & $(1.00)$ \\
\hline \multirow[t]{2}{*}{ Model dummy (SVAR-AB) } & 0.262 & 0.147 & $0.373^{* * *}$ & $0.240^{*}$ & 0.005 & 0.015 & $2.906^{*}$ & $2.942^{*}$ \\
\hline & $(1.68)$ & $(0.79)$ & $(4.37)$ & $(2.42)$ & $(0.03)$ & $(0.10)$ & $(2.36)$ & $(2.29)$ \\
\hline \multirow[t]{2}{*}{ Quarterly data dummy } & 0.167 & 0.137 & $(0.005)$ & 0.065 & 0.069 & 0.054 & $2.688^{*}$ & $2.076^{*}$ \\
\hline & $(0.98)$ & $(0.76)$ & $(0.05)$ & $(0.65)$ & $(0.41)$ & $(0.34)$ & $(2.25)$ & $(2.15)$ \\
\hline \multirow[t]{2}{*}{ Constant } & $-2.135^{*}$ & $-1.834^{*}$ & 0.072 & -0.094 & $-2.573^{* *}$ & $-2.594^{* *}$ & $20.160^{* *}$ & 10.460 \\
\hline & $(2.43)$ & $(2.01)$ & $(0.15)$ & $(0.18)$ & $(3.03)$ & $(3.30)$ & $(3.30)$ & $(1.41)$ \\
\hline$N$ & 170 & 170 & 184 & 184 & 178 & 178 & 169 & 169 \\
\hline $\operatorname{Adj} R^{2}$ & 0.164 & 0.177 & 0.270 & 0.096 & 0.193 & 0.256 & 0.269 & 0.209 \\
\hline
\end{tabular}

indicate statistical significance: ${ }^{*}$ significant at the $10 \%$ level; ${ }^{* *}$ significant at the $5 \%$ level; ${ }^{* * *}$ significant at the $1 \%$ level. 


\section{Conclusion}

In this paper we have used meta-analysis to identify sources of variation of the (regional) output effects of monetary policy, particularly in the US and Europe. The output effects are typically characterized by an inverted hump-shaped response pattern following monetary policy contractionary actions. Yet, we found that there is a large variation of the output effects in terms of their size and timing across regions/countries in our sample of observations. Having controlled for variation in study characteristics, we are able to point to some key determining sources of variation of the impact of monetary policy. First, manufacturing (as a percentage of $\mathrm{G}(\mathrm{R}) \mathrm{DP})$ as a proxy of capital intensity clearly contributes to explain cross-sectional variation in policy responses. Thereby, it provides evidence for the relevance of the interest rate channel of monetary policy. Second, an important role was found for variation in financial development (proxied by stock market capitalization (as a percentage of G(R)DP)). An economy with more alternative funding sources created by a well-developed capital market alleviates the negative impact of monetary shocks. Next, variation in the rate of inflation was also found to significantly contribute to the differential output effects. Given the price misperception phenomenon (the Lucas model), an economy with a high inflation regime tends to be less responsive to monetary policy innovations, and thereby faces a higher economic cost of facilitating its economic development. Finally, our findings underline variation in economic size as an important factor. Small economies experience larger relative output losses following a monetary contraction than larger ones. The phenomenon might be related to the small region's economic specialization, lack of development (institutions), and a poorer bargaining position in the political arena. This dual pattern indicates a relatively close resemblance to the core-periphery phenomenon that is distinguished in the literature on asymmetric shocks. The phenomenon mainly asserts that a core region has more advantages in utilizing a national monetary policy to stimulate its growth as compared with the periphery. As a consequence, monetary policy impacts will also raise distributional implications across regions or countries within a monetary union. The latter issue is left for further research. 


\section{References}

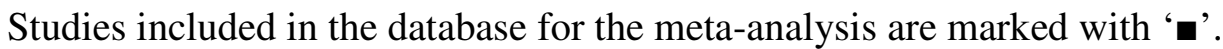

Abreu, M., de Groot, H. L. F. and Florax, R. J. G. M. (2005). A meta-analysis of $\beta$ convergence: the legendary 2\%. Journal of Economic Surveys 19: 389-420.

Amisano, G. and Giannini, C. (1997). Topics in structural VAR econometrics. New York: Springer.

Anzuini, A. and Levy, A. (2007). Monetary policy shocks in the new EU members: A VAR approach. Applied Economics 39(9): 1147-1162.

Alesina, A., Spolaore, E. and Wacziarg, R. (2005). Trade, growth and the size of countries. In: P. Aghion and S. Durlauf (eds), Handbook of Economic Growth. North Holland: Elsevier.

Barth III, M. J. and. Ramey, V. A. (2001). The cost channel of monetary transmission. NBER Macroeconomics Annual 16: 199-240.

Bernanke, B. S. and Blinder, A. S. (1992). The federal funds rate and the channels of monetary transmission. American Economic Review 82(4): 901-921.

Bernanke, B. S. (1986). Alternative explanations of money-income correlation. CarnegieRochester Conference Series on Public Policy 25: 49-100.

Bernanke, B. S. and Gertler, M. (1995). Inside the black box, the credit channel of monetary policy transmission. Journal of Economic Perspectives 9: 27-48.

Blanchard, O. J. and Quah, D. (1989). The dynamic effects of aggregate demand and supply disturbances. American Economic Review 79(4): 655-673.

Card, D. and Krueger, A. B. (1995) Time-series minimum-wage studies: a meta-analysis. American Economic Review 85: 238-243.

Carlino, G. and DeFina, R. H. (1998). The differential regional effects of monetary policy. Review of Economics and Statistics 80: 572-587.

Carlino, G. and DeFina, R. H. (1999). The differential regional effects of monetary policy: evidence from the U.S. States. Journal of Regional Science 39: 339-358.

Cecchetti, S. G. (1999). Legal structure, financial structure, and the monetary policy transmission mechanism. National Bureau of Economic Research, Working Paper no. 7151.

Cecchetti, S. G. and Perez-Quiros, G. (2002). Policymakers' revealed preferences and the output-inflation variability trade-off: Implications for the European system of central banks. The Manchester School 70(4): 596-618.

Christiano, L. J., Eichenbaum, M. and Evans, C. (1996). The effects of monetary policy shocks: evidence from the flow of funds. Review of Economics and Statistics 78: 16-34.

Clements, B., Kontolemis, Z., Levy, J., and Joaquim, V. (2001) Monetary policy under EMU: Differences in the transmission mechanism. IMF, Working Paper no. 01/102.

Cochrane, J. H. (1998). What do the VARs mean? Measuring the output effects of monetary policy. Journal of Monetary Economics 41: 277-300.

Cover, J. P. (1992). Asymmetric effects of positive and negative money-supply shocks. Quarterly Journal of Economics 107(4): 1261-1282.

Dedola, L. and Lippi, F. (2005). The monetary transmission mechanism: Evidence from the industries of five OECD countries. European Economic Review 49: 1543-1569.

De Grauwe, P. and Storti, C. C. (2004). The effects of monetary policy: A meta-analysis CESIFO, Working Paper no. 1224. 
De Long, J. B., Summers, L. H., Mankiw, N. G. and Romer, C. D. (1988). How does macroeconomic policy affect output? Brookings Papers on Economic Activity 2: 433-494.

Ehrmann, M. (1998). Will EMU generate asymmetry? Comparing monetary policy transmission across European countries. EUI, Working Paper no. 28.

Elbourne, A. and de Haan, J. (2004). Asymmetric monetary transmission in EMU: The robustness of VAR conclusions and Cecchetti's legal family theory. CESIFO, Working Paper no. 1327.

Elbourne, A. and de Haan, J. (2006). Financial structure and monetary policy transmission in transition countries. Journal of Comparative Economics 34 (1): 1-23.

Enders, W. (2004). Applied Econometrics Time Series. Hoboken, NJ: John Wiley and Sons.

Faust, J. (1998). The robustness of identified VAR conclusions about money. CarnegieRochester Conference Series on Public Policy 49: 207-244.

Favero, C. A. (2001). Applied Macroeconometrics. Oxford: Oxford University Press.

Fischer, S. (1996). Why are central banks pursuing long-run price stability? In: Achieving Price Stability. Federal Reserve Bank of Kansas City Symposium Paper, http://www.kansascityfed.org/publicat/sympos/1996/pdf/s96fisch.pdf

Fishkind, H. H. (1977). The regional impact of monetary policy: An economic simulation study of Indiana (1958-1973). Journal of Regional Science 17: 77-88.

Florax, R. J. G. M., de Groot, H. L. F. and de Mooij, R. A. (2002). Meta-analysis: A tool for upgrading inputs of macroeconomic policy models. Tinbergen Institute, Discussion Paper no. $2002-041 / 3$.

Florio, A. (2004). The asymmetric effects of monetary policy. Journal of Economic Surveys 18(3): 409-426.

Frantantoni, M. and Schuh, S. (2003). Monetary policy, housing, and heterogeneous regional markets. Journal of Money, Credit and Banking 35: 557-589.

Ganley, J. and Salmon, C. (1997). The industrial impact of monetary policy shocks: some stylised facts. Bank of England, Working Paper no. 68.

Gali, J. (1992). How well does the IS-LM model fit postwar US data? Quarterly Journal of Economics 107(2): 709-738.

Garrison, C. B. and Chang, H. S. (1979). The effect of monetary and fiscal policies on regional business cycles. International Regional Science Review 4: 167-180.

Gerlach, S. and Smets, F. (1995). The monetary transmission mechanism: evidence from the G-7 countries. BIS, Working Paper no. 26.

Glass, G. V. (1976). Primary, secondary, and meta-analysis of research. Educational Researcher 5(10), 3-8.

Gorg, H. and Strobl, E. (2001). Multinational companies and productivity spillovers: A metaanalysis. Economic Journal 111: F723-F739.

Greene, W. H. (2008). Econometric Analysis, $6^{\text {th }}$ edn. Upper Saddle River, NJ: Prentice Hall International.

Gujarati, D. N. (2003). Basic Econometrics, $4^{\text {th }}$ edn. New York: McGraw-Hill Higher Education.

Hayo, B., and Uhlenbrock, B. (1999) Sectoral Effects of Monetary Policy in Germany. In: J. von Hagen and C. Waller (eds.), Common Money, Uncommon Regions. Kluwer Academic Publishers.

Homes, M. J. (2000). Monetary shocks and the asymmetric adjustment of UK regional output. Environment and Planning C: Government and Policy 18: 667-680. 
Kalemli-Ozcan, S., Sørensen, B.E. and Yosha, O. (2001) Economic integration, industrial specialization, and the asymmetry of macroeconomic fluctuations. Journal of International Economics 55(1): 107-137.

Karras, G. (1996). Are the output effects of monetary policy asymmetric? Evidence from a sample of European countries. Oxford Bulletin of Economics and Statistics 58(2): 267-278.

Keef, S. P. and Roberts, L. A. (2004). The meta-analysis of partial effect sizes. British Journal of Mathematical and Statistical Psychology 57(1): 97-129.

Kalaitzidakis, P., Mamuneas, T. P. and Stengos, T. (2003). Rankings of academic journals and institutions in economics. Journal of the European Economic Association 1(6): 1346-1366.

Kieler, M. and Saarenheimo, T. (1998). Differences in monetary policy transmission? A case not closed. European Commission, Economic Papers no. II/407.

King, R. G., Plosser, C. I., Stock, J. H. and Watson, M. W. (1991). Stochastic trends and economic fluctuations. American Economic Review 81(4): 819-840.

King, R. G. and Levine, R. (1993). Finance and growth: Schumpeter might be right. Quarterly Journal of Economics 108(3): 717-737.

Kiviet, B., Elbourne, A. and de Haan, J. (2003). Financial structure and monetary policy transmission in transition countries. Rijksuniversiteit Groningen Working Paper, www.eco.rug.nl/medewerk/sterken/download/transition.pdf.

Knell, M. and Stix, H. (2005). The income elasticity of money demand: A meta-analysis of empirical results. Journal of Economic Surveys 19(3): 513-533.

Krueger, A. B. (2003). Economic considerations and class size. Economic Journal 113: F34-F63.

Leeper, E. M., Sims, C. A. and Zha, T. (1996). What does monetary policy do? Brookings Papers on Economic Activity 2: 1-63.

Levine, R., Loayza, N. and Beck, T. (2000). Financial intermediation and growth: Causality and causes. Journal of Monetary Economics 46: 31-77.

Lucas, R. E. (1972). Expectations and the neutrality of money. Journal of Economic Theory 4(2): 103-124.

Lütkepohl, H. (2007). New Introduction to Multiple Time Series Analysis, $2^{\text {nd }}$ edn. Berlin, Springer.

Mihov, I. (2001). One monetary policy in EMU. Economic Policy 33: 369-406.

Miller, R. J. (1978). The Regional Impact of Monetary Policy in the United States. Lexington, MA: Lexington Books.

Mishkin, F. S. (1995). Symposium on the monetary transmission mechanism. Journal of Economic Perspectives 9: 3-10.

Mishkin, F. S. (1996). The channels of monetary transmission: lessons for monetary policy. National Bureau of Economic Research, Working Paper no. 5464.

Nijkamp, P. and Poot, J. (2004). Meta-analysis of the effect of fiscal policies on long-run growth. European Journal of Political Economy 20(1): 91-124.

Owyang, M. T. and Wall, H. J. (2004). Structural breaks and regional disparities in the transmission of monetary policy. Federal Reserve Bank of St. Louis, Working Paper no. 2003-008C.

Peersman, G. (2004). The transmission of monetary policy in the Euro Area: Are the effects different across countries? Oxford Bulletin of Economics and Statistics 66(3): 285-308.

Peersman, G. and Smets, F. (2005). The industry effects of monetary policy in the euro area. Economic Journal 115: 319-342. 
Pitzel, D. and Uuskula, L. (2005). The effect of financial depth on monetary transmission. Eesti Bank, Working Paper no. 10.

Pons-Novell, J. and Tirado-Fabregat, D. (2006). Specialization and asymmetries in macroeconomic fluctuations: Evidence for the European regions. Regional Studies 40(7): 695-706.

Ramaswamy, R. and Sløk, T. (1998). The real effects of monetary policy in the European Union: What are the differences? Staff Papers - International Monetary Fund 45(2): 374-396.

Ridhwan, M. M., Nijkamp, P., Rietveld, P. and de Groot, H. L. F. (2008). Regional development and monetary policy: A review of the role of monetary unions, capital mobility and locational effects. VU Amsterdam, Research Memoranda no. 0007.

Rose, A. K. and Stanley, T. D. (2005). A meta-analysis of the effect of common currencies on international trade. Journal of Economic Surveys 19(3): 347-365.

Schunk, D. (2005). The differential impacts of monetary policy: Are the differences diminishing? Papers in Regional Science 84(1): 127-136.

Shapiro, M. D. and Watson, M. W. (1988). Sources of business cycle fluctuations. NBER Macroeconomic Annual 3: 111-148.

Sims, C. A. (1980). Macroeconomics and reality. Econometrica 48: 1-48.

Sims, C. A. (1986). Are forecasting models usable for policy analysis. Federal Reserve Bank of Minneapolis Quarterly Review (Winter edition): 3-16.

Sims, C. A. (1992). Interpreting the macroeconomic time series facts: The effects of monetary policy. European Economic Review 36: 975-1011.

Smith, V. K. and Huang, J. C. (1995). Can markets value air quality? A meta-analysis of hedonic property value models. Journal of Political Economy 103: 209-227.

Stanley, T. D. (2005). Beyond publication bias. Journal of Economic Surveys 19(3): 309-345.

Stanley, T. D. and Jarrell, S. B. (1989). Meta-regression analysis: A quantitative method of literature surveys. Journal of Economic Surveys 19(3): 299-308.

Weichselbaumer, D. and Winter-Ebmer, R. (2005). A meta-analysis of the international wage gender gap. Journal of Economic Surveys 19(3): 479-511.

Ziliak, S. T. and McCloskey. D. N. (2004). Significance redux. Journal of Socio-Economics 33 : 665-675. 
Appendix A. Descriptive statistics of variables used in the meta-analysis regression

\begin{tabular}{|c|c|c|c|c|c|}
\hline Meta Variables & Obs & Mean & Std. Dev. & Min & Max \\
\hline \multicolumn{6}{|l|}{ Dependent variables } \\
\hline $\begin{array}{l}\text { Output effect of monetary shock at the maximum } \\
\text { level (maximum effect) }\end{array}$ & 170 & -0.77 & 0.64 & -2.94 & 0.00 \\
\hline $\begin{array}{l}\text { Output effect of monetary shock in the } 4 \text { th quarter } \\
\text { (short-run effect) }\end{array}$ & 184 & -0.53 & 0.60 & -2.87 & 0.00 \\
\hline $\begin{array}{l}\text { Output effect of monetary shock in the 16th quarter } \\
\text { (medium-run effect) }\end{array}$ & 178 & -0.34 & 0.34 & -1.88 & 0.07 \\
\hline Time-elapsed at the maximum effect & 169 & 8.28 & 4.50 & 0.33 & 20.00 \\
\hline
\end{tabular}

\section{Restriction type and data characteristics}

Dummy for identification and restriction scheme

- VAR-B: recursive VAR with Choleski decomposition (Christiano et al., 1996)

- SVAR: structural VAR with non recursive contemporaneous restriction (Sims, 1986; Bernanke, 1986)

- SVAR-AB: AB-Model (Gali, 1992)

- VECM: VAR with co-integration factor (King et al., 1991)

$\begin{array}{llll}0.14 & 0.35 & 0.00 & 1.00\end{array}$

Dummy for model dimension:

- Basic form (four dimensions: price, output, interest rate, and money supply/credit)

- Basic form with exchange rate added

- Basic form with exchange rate, commodity price, and foreign interest rate added

Dummy output variable :

- G(R)DP (gross (regional) domestic products)

- Total personal income

- Industrial production index

Number of degrees of freedom

Sample size

Journal rank

Temporal characteristics:

- Year of publication

- Midpoint of observation period 
- Midpoint of observation period (standardized value) 185

- Initial year of the sample

- End of period the sample

- Time frequency data (monthly)

- Time frequency data (quarterly)

- Dummy for the 1960 s data used

- Dummy for the 1970 s data used

- Dummy for the 1980s data used

- Dummy for the 1990 s data used

- Length of observation period (in quarters)

- Length of time-lag used in sample (quarters)

\section{Conditioning variables}

Capital intensity measure (sum of manufacturing and construction shares - $\%$ of GDP)

Share of manufacturing sector (\% of GDP)

Share of construction sector (\% of GDP)

Rate of inflation (\%)

Economic size (log GDP in US dollars)

Exports (\% of GDP)

Bank-credits to private sector (\% of GDP)

Number of bank-offices per 100,000 people (log)

Stock market capitalization (\% of GDP)

Dummy for floating exchange rate regime

Dummy for pegged exchange rate regime

Population size or number of people (in $\log$ )

Geographical and temporal characteristics:

- Country-level dummy

- Regional-level dummy

- USA dummy

- Eurozone (EMU) dummy

- European union (non-eurozone) dummy
185

185

185

185

185

185

185

185

185

185

185

185

185

185

185

185

185

\begin{tabular}{rrrr}
0.01 & 1.00 & -1.73 & 2.01 \\
1972.48 & 12.53 & 1958.00 & 1998.00 \\
1995.11 & 6.33 & 1978.00 & 2004.00 \\
0.16 & 0.36 & 0.00 & 1.00 \\
0.84 & 0.36 & 0.00 & 1.00 \\
0.04 & 0.20 & 0.00 & 1.00 \\
0.34 & 0.47 & 0.00 & 1.00 \\
0.29 & 0.45 & 0.00 & 1.00 \\
0.34 & 0.47 & 0.00 & 1.00 \\
103.10 & 37.77 & 42.00 & 228.00 \\
3.11 & 0.92 & 1.00 & 5.00 \\
\hline
\end{tabular}

35.35

28.07

7.28

8.68

18.86

24.09

57.47

34.55

50.29

0.54

0.46

16.25

0.57

0.50

0.00

1.00

0.43

0.50

0.00

1.00

0.43

0.50

0.00

1.00

0.40

0.49

0.00

1.00

0.17

0.37
0.00 